\title{
Evaluation of Microbially Induced Calcite Precipitation (MICP) methods on different soil types for wind erosion control
}

\author{
Seung Hee Chae, Hyeonyong Chung, Kyoungphile Nam ${ }^{\dagger}$ \\ Department of Civil and Environmental Engineering, Seoul National University, Seoul, South Korea
}

\begin{abstract}
Application methods (i.e., pouring and mixing method) of Microbially Induced Calcite Precipitation (MICP) and its effect on wind erosion were investigated on four soil types (i.e., medium sand, fine sand, loamy fine sand and loam). With mixing method, calcite precipitated evenly throughout the upper part $(0-5 \mathrm{~cm})$ of all the soils tested, but with pouring method, only medium sand showed even calcite distribution. The reason can be ascribed to the limited permeability of MICP-inducing solution (i.e., calcium, urea and Sporosarcina pasteurii) through loamy fine sand and loam due to their low hydraulic conductivity (i.e., $<10^{-5} \mathrm{~cm} / \mathrm{s}$ ). Moreover, bacterial penetrability was also reduced by calcium (i.e., 70 to $20 \%$ ) in fine sand. Hence, pouring method for medium sand and mixing method for the others were applied with various MICP-inducing solution concentrations (i.e., 0.1 to $1 \mathrm{M}$ of urea and calcium). When exposed to wind of $15 \mathrm{~m} / \mathrm{s}$ after MICP application, $0.25 \mathrm{M}$ solution in medium and fine sand, and $0.1 \mathrm{M}$ solution in loamy fine sand and loam showed little or no soil loss. The results suggest that a proper application method be chosen considering soil properties that affect even calcite distribution to mitigate soil erosion.
\end{abstract}

Keywords: Microbially induced calcite precipitation (MICP), Soil erosion, Soil treatment, Wind erosion control

\section{Introduction}

Soil particles in the atmosphere adsorb toxic chemicals before getting uptake by humans causing adverse effects such as respiratory diseases [1]. Several efforts to minimize soil dust formation were made in particular, forestation and chemical solidification, but none have shown to be fully effective [2]. Amount of soil dust eroded from the surface varies by the surface wind velocity and soil properties such as particle size distribution and moisture content. Once the wind exerts a force bigger than the frictional force between soil particles that is when the wind overcomes the threshold wind speed to separate soil particles from the soil [3]. Threshold wind speed increases as soil contains more moisture [4], as a result, soil in desert areas has the lowest threshold wind speed and prone to wind erosion. Also, large particles are more affected by gravity where small particles have stronger interparticle cohesion [5] suggesting that the relationship between wind erosion and particle size must be concerned. Therefore, there was a need to suggest a way to efficiently reduce soil erosion at soils of different particle sizes.

Microbially Induced Calcite Precipitation (MICP) produces calcium carbonate through microbial activity. Three components, ure-

This is an Open Access article distributed under the terms of the Creative Commons Attribution Non-Commercial License (http://creativecommons.org/licenses/by-nc/3.0/) which permits unrestricted non-commercial use, distribution, and reproduction in any medium, provided the original work is properly cited.

Copyright (C) 2021 Korean Society of Environmental Engineers ase-secreting microorganism, calcium ion and urea, should be present for MICP to be applied. With these components present, MICP occurs in two steps, urea hydrolysis and $\mathrm{CaCO}_{3}$ precipitation. Urease-secreting microorganism plays a role in the urea hydrolysis reaction by secreting urease enzyme externally. The most commonly used urease-secreting microorganism is Sporosarcina pasteurii (aka. Bacillus pasteurii) which is an aerobic microorganism found in soils that secrete urease during the ATP production process [6-9]. When one mole of urea $\left(\mathrm{CO}\left(\mathrm{NH}_{2}\right)_{2}\right)$ hydrolyzes, one mole of carbonate ion and two moles of ammonium ion are produced (Eq. (1)). The increasing ammonium concentration causes the sharp increase of $\mathrm{pH}$ thus forming a favorable environment for $\mathrm{CaCO}_{3}$ precipitation (Eq. (2)). For the $\mathrm{CaCO}_{3}$ precipitation reaction, calcium ion is supplied by the external addition of calcium chloride and the carbonate ion comes from the product of urea hydrolysis reaction [10].

$$
\begin{gathered}
\mathrm{CO}\left(\mathrm{NH}_{2}\right)_{2}+2 \mathrm{H}_{2} \mathrm{O} \rightarrow \mathrm{CO}_{3}^{2-}+2 \mathrm{NH}_{4}^{+} \\
\mathrm{Ca}^{2+}+\mathrm{CO}_{3}^{2-} \rightarrow \mathrm{CaCO}_{3}(s)
\end{gathered}
$$

The precipitated calcium carbonate serves as a bridge between

\footnotetext{
$\dagger$ Corresponding author

Email: kpnam@snu.ac.kr

Tel: +82-2-880-1448 Fax: +82-2-873-2684

ORCID: 0000-0001-7383-2973
} 
soil particles, consolidating the soil. Also, due to its environmental friendliness, reinforcing the soil without any specific chemicals, this technique has found to be useful in diverse applications. It is used to stabilize the ground soil by increasing soil strength and stiffness [7, 11, 12], or used to repair concrete cracks [13], or even to bioimmobilize heavy metals $[14,15]$. Recently, S.E. Lambert et al. [16] reported successful manufacture of bio-bricks having compressive strength of $2.7 \mathrm{MPa}$ by incorporating human urine as a source for urea and calcium. This study once more emphasized the environmental friendly and energy efficient aspect of MICP application.

Although there were some studies applying MICP to increase wind erosion resistance of soil, these studies only considered its application on sandy soils by directly applying the MICP-inducing solution on the soil surface $[17,18]$. Also, former studies only applied MICP on one type of sandy soil just by changing the concentration or the application number of MICP-inducing solution. S. Bang et al. [19] and $\mathrm{Gu}$ et al. [20] have applied MICP on two types of soils, poorly graded sand and well graded sand, which again did not consider soils with different particle sizes. However, since the soil composition of major deserts (Takla Makan Desert, Gobi Desert, Loess Area) vary from sand to silty sandy loam [21-23], the way to apply MICP on soils mainly containing silt and clay must be devised.

Therefore, in this study, additional MICP application method (i.e., mixing method) was conceived and compared with the conventional method on different types of soils. The optimal MICP application method was selected for each type of soils by comparing the amount of calcite precipitation. After applying the optimal method of MICP with different $\mathrm{Ca}^{2+}$ and urea concentration, soil samples were tested for wind erosion resistance. From the experiment, the lowest concentration of MICP-inducing solution which could maintain stable wind erosion resistance was determined.

\section{Material and Methods}

\subsection{Preparation of Soil Samples}

The standard of sorting sand and silt is $75 \mu \mathrm{m}$ but because this study was conducted to measure the wind erosion resistance of MICP, $100 \mu \mathrm{m}$, particle size with the smallest threshold friction velocity [24] was selected. Hence, the lower limit of separating particles was set to $106 \mu \mathrm{m}$ by using BSS standard \#150 sieve. For the upper limit, $250 \mu \mathrm{m}$, the criterion for separating medium and fine sand was chosen. Silica sand (i.e., \#5, 30 - 60 mesh; Joomoonjin Silica Sand Co.) was grinded with ball mill and was sorted with two sieves, BSS standard \#60 (i.e., $250 \mu \mathrm{m}$ ) and \#150 (i.e., $106 \mu \mathrm{m}$ ), using a sieve shaker (CISA-CEDACERIA, ES/Sieve Shaker RP09). After preparing > $250 \mu \mathrm{m}, 106-250 \mu \mathrm{m}$ and < $106 \mu \mathrm{m}$ soil, the last two soils were mixed proportionately to make the loamy fine sand. $<106 \mu \mathrm{m}$ soil was confirmed to be loam by NICEM (National Instrumentation Center for Environmental Management). As a result, loamy fine sand and loam was composed of sand, silt and clay, where loamy fine sand had a respective ratio of $76 \%, 19 \%$ and $5 \%$ and for loam, $52 \%, 38 \%$ and $10 \%$. Therefore, $>250 \mu \mathrm{m}$ soil was sorted to be medium sand (S), 106 - $250 \mu \mathrm{m}$ soil as fine sand (FS), mixture of $106-250 \mu \mathrm{m}$ soil and $<106 \mu \mathrm{m}$ soil as loamy find sand (LFS) and $<106$ soil as loam (L).

\subsection{Measuring Physio-chemical Properties of Soil Samples}

Four properties of soil, Cation Exchange Capacity (CEC), pH, field capacity and hydraulic conductivity were further analyzed. CEC was measured by using sodium acetate suggested by USEPA [25]. $\mathrm{pH}$ of soil samples were measured by using a simple method suggested by Gillman [26]. In order to measure the field capacity, soil samples were fully saturated and then applied with the pressure of $-1 / 3$ bar to extract excess water. The wet soil samples were dried in $65^{\circ} \mathrm{C}$ oven for $24 \mathrm{~h}$ and the mass difference between the wet and dry state of soils was used to calculate the field capacity. For the measurement of hydraulic conductivity, constant-head method was used for medium sand and falling-head method for the rest of soil samples. Particle size distribution and physio-chemical properties of soil samples are stated in Table 1. Briefly, cation exchange capacity was similar between the two sand samples; $0.89 \mathrm{meq} / 100$ g-soil for medium sand and $0.91 \mathrm{meq} / 100 \mathrm{~g}$-soil for fine sand, but showed difference from loamy fine sand and loam (i.e., $1.50 \mathrm{meq} / 100$ g-soil and $1.89 \mathrm{meq} / 100$ g-soil, respectively). All soil $\mathrm{pH}$ were in between 6.5 to 7.5 showing a little variance, which were adequate for $S$. pasteurii to exhibit their urease activity, since there is no difference in between $\mathrm{pH}$ range of 6 to 9 [27].

\subsection{Cultivation of Sporosarcina Pasteurii}

For urease secreting microorganism, Sporosarcina pasteurii (S. pasteurii) was selected following other MICP studies [6-9]. Growth medium of $S$. pasteurii was prepared by autoclaving $1.9 \mathrm{~L}$ solution with $60 \mathrm{~g}$ of Tryptic soy broth (TSB). After the autoclaved solution had cooled down to room temperature, $100 \mathrm{~mL}$ of $12 \mathrm{~g}$ urea solution was added by filtration with $0.22 \mu \mathrm{m}$ filter to make $2 \mathrm{~L}$ of 30 g/L TSB and 6 g/L urea solution. After autoclaving the bottle, growth medium was added to make a headspace of 8:1. S. pasteurii stock was added to the growth medium which was then incubated at $30^{\circ} \mathrm{C}$ for $24 \mathrm{~h}$. The growth medium was then centrifuged (IECMULTI-RF, Thermo scientific, USA) at $14000 \mathrm{XG}$ for $8 \mathrm{~min}$

Table 1. Texture of Soil Samples

\begin{tabular}{|c|c|c|c|c|c|c|c|}
\hline \multirow{2}{*}{ Soil texture } & \multicolumn{3}{|c|}{ Sand (\%) } & \multirow{2}{*}{$\begin{array}{c}\text { Silt (\%) } \\
75-2 \mu \mathrm{m}\end{array}$} & \multirow{2}{*}{$\begin{array}{l}\text { Clay (\%) } \\
<2 \mu \mathrm{m}\end{array}$} & \multirow{2}{*}{$\begin{array}{c}\text { CEC } \\
\text { (meq/100 g-soil) }\end{array}$} & \multirow{2}{*}{ pH } \\
\hline & $>250 \mu \mathrm{m}$ & $250-106 \mu \mathrm{m}$ & $106-75 \mu \mathrm{m}$ & & & & \\
\hline Medium sand (S) & 100 & & & 0 & 0 & 0.89 & 6.72 \\
\hline Fine sand (FS) & & 100 & & 0 & 0 & 0.91 & 7.19 \\
\hline Loamy fine sand (LFS) & & 50 & 26 & 19 & 5 & 1.50 & 7.16 \\
\hline Loam (L) & & & 52 & 38 & 10 & 1.89 & 7.43 \\
\hline
\end{tabular}


and once again dissolved to PBS solution. Spectrometric method (Optizen 2100UV, CP corp., Korea) was used to measure the OD of the solution which was then diluted with PBS solution.

\subsection{MICP Application on Soil Samples (Pouring and Mixing Method)}

Two different methods of MICP application was tested for all samples. The first method, pouring method, applies MICP by pouring the MICP-inducing solution on top of the soil surface. The second method, mixing method, mixes the MICP-inducing solution and soil beforehand and then places the mixture in the reactor. In order for the excess MICP-inducing solution to be drained, there needed to be a hole at the bottom of the reactor. Hence, in this study, $30 \mathrm{~mL}$ syringe was used with a $11 \mu \mathrm{m}$ filter and $1 \mathrm{~cm}$ of glass bead layer at the bottom to avoid leaching of soil and the accumulation of $S$. pasteurii. On top of the glass bead layer, 40 $\mathrm{g}$ of each soil samples were placed.

For both methods, the concentration of MICP-inducing solution was as follows, $1 \mathrm{M}$ of urea and calcium with OD 1 of $S$. pasteurii. Total of $15 \mathrm{~mL}$ was used for each method and as stated, excess solution could be drained through the syringe hole. To keep $S$. pasteurii from stacking on top of the soil, when pouring method was applied, $5 \mathrm{~mL}$ of MICP-inducing solution was injected over three times. For the mixing method, $15 \mathrm{~mL}$ of MICP solution and $40 \mathrm{~g}$ of soil samples were mixed together and then put into the reactor. After applying $15 \mathrm{~mL}$ MCP-inducing solution, reactors were put into $25^{\circ} \mathrm{C}$ incubator for $24 \mathrm{~h}$. The amount of precipitated calcite was measured at depth $0,2.5$ and $5 \mathrm{~cm}$ from the surface. Only until soil depth of $5 \mathrm{~cm}$ was considered since $0-5 \mathrm{~cm}$ of surface soil is considered as upper topsoil which is most prone for wind erosion [28]. At each depth, $5 \mathrm{~g}$ of samples were collected and put into $50 \mathrm{~mL}$ conical tube. $25 \mathrm{~mL}$ of water was mixed with the soil sample to remove the remaining unreacted calcium ions and was centrifuged at $14000 \mathrm{XG}$ for $8 \mathrm{~min}$. The supernatant was filtered with $0.22 \mu \mathrm{m}$ filter and Ca concentration of the supernatant was measured. Precipitates of centrifuged DI water and soil mixture were washed again with $25 \mathrm{~mL}$ of $1 \mathrm{M} \mathrm{HCl}$ solution to dissolve the precipitated calcites. Again, the mixture was centrifuged with the same condition and was filtered to measure the Ca concentration. Calcium concentrations for the both solutions were measured using ICP (ICP-OES iCAP 7400). The Ca concentration measured after washing the soil with $\mathrm{HCl}$ solution was assumed to be the results of calcium carbonate precipitates in the soil. Hence, the amount of precipitated calcite was calculated from the measured Ca concentration.

\subsection{Microbial Activity at $0,2.5$ and $5 \mathrm{~cm}$ Soil Depths and the Influence of $\mathrm{Ca}$ Ion}

To characterize the difference between soil samples that resulted in a limited appliance of pouring method, penetrability of $S$. pasteurii was examined. All settings were identical as the calcite precipitation experiment (i.e., $30 \mathrm{~mL}$ syringe, $11 \mu \mathrm{m}$ filter, glass beads, $40 \mathrm{~g}$ of soil) but this time, only $15 \mathrm{~mL}$ of OD 1 solution was injected. As for the next experiment examining the influence of calcium ion on microbial activity by depth, $15 \mathrm{~mL}$ of OD 1, $1 \mathrm{M}$ Ca was used. After injection of the solution, $4 \mathrm{~g}$ of soil were collected at depth 0, 2.5 and $5 \mathrm{~cm}$ from the surface. $2 \mathrm{~g}$ of the soil sample was weighed and after putting it in the $65^{\circ} \mathrm{C}$ oven for $24 \mathrm{~h}$, was weighed again to measure the moisture content of the soil. The other $2 \mathrm{~g}$ soil was put into $50 \mathrm{~mL}$ conical tube filled with 25 $\mathrm{mL}$ of $1 \mathrm{M}$ urea solution. Reaction time of $10 \mathrm{~min}$ was given for each sample which was then filtered with $0.22 \mu \mathrm{m}$ filter. The concentration of ammonia, product of urease hydrolysis, was measured via Nessler's Reagent spectrophotometry. The initial amount of ammonium was not detected with Nessler's Reagent spectrophotometry meaning that the concentration of ammonium was below the detection limit of $0.1 \mathrm{M}$.

\subsection{Wind Erosion Measurement After MICP Application}

$40 \mathrm{~g}$ of each soil samples were placed in a petri dish (i.e., diameter: $6 \mathrm{~cm}$, depth: $1.2 \mathrm{~cm}$ ) and MICP-inducing solution with various $\mathrm{Ca}$ and urea concentrations (i.e., 0, 0.1, 0.25, 0.5 and $1 \mathrm{M}$ ) and OD 1 of $S$. pasteurii was applied to each soil samples. For medium sand, the MICP-inducing solution was injected by pouring method and for the other soil types, the solution and soil samples were mixed beforehand. After injection, soil samples were placed in the $25^{\circ} \mathrm{C}$ incubator for $24 \mathrm{~h}$ for calcite precipitation. To measure the wind erosion rate, the surface of the soil sample was exposed to the $15 \mathrm{~m} / \mathrm{s}$ wind coming from $10^{\circ}$. Wind speed of $15 \mathrm{~m} / \mathrm{s}$ was selected since the wind speed during typical dust storms was in between 10 to $20 \mathrm{~m} / \mathrm{s}$ [29]. The mass of the soil sample was compared before and after the exposure to calculate the wind erosion rate.

\section{Results and Discussion}

\subsection{Comparison of Calcite Precipitation Between Pouring and Mixing Method}

Amount of precipitated calcite was measured at three depth points (i.e., 0, 2.5 and $5 \mathrm{~cm}$ ) and then compared between two different methods of MICP application (i.e., pouring and mixing method). As a result, shown in Fig. 1, mixing method induced even calcite precipitation throughout the soil for all soil types but pouring method only did so for medium sand and for other soils, calcite accumulated mostly on the surface. Furthermore, comparing the total amount of precipitated calcite in medium sand, more precipitation was induced when pouring method was implemented. Therefore, the pouring method was only adequate for medium sand and from fine sand to finer soils, mixing method derived more calcite precipitation.

In order to analyze why the pouring method could only be applied to medium sand, permeability of MICP-inducing solution (Sporosarcina pasteurii, urea and calcium ion) was examined. The overall solution permeability was determined by measuring the field capacity and hydraulic conductivity of each soil samples. As Fig. 2(a) shows, field capacity increased as particle size decreased, that of medium sand being 6.35 g-water/g-soil, fine sand of 9.29 g-water/g-soil, loamy fine sand of 17.80 g-water/g-soil to loam being $22.41 \mathrm{~g}$-water/g-soil. These results show that enough calcite can be formed to solidify the soil in upper conditions since 0.5 to $5 \mathrm{~g}$ of calcite per $\mathrm{cm}^{3}$ of soil can lead to sufficient wind resistance of soil according to Maleki [18]. 

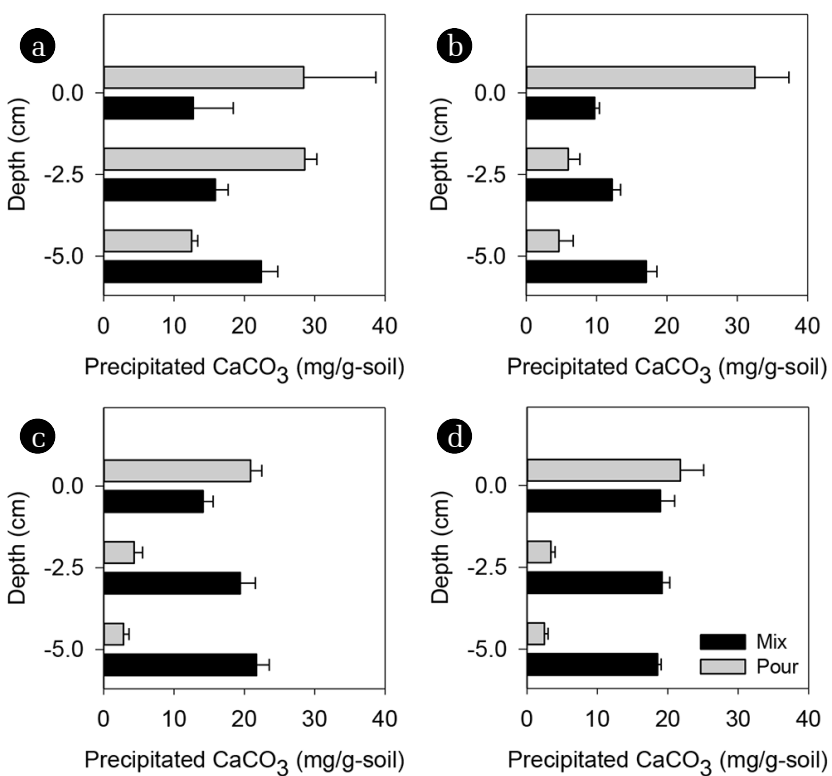

Fig. 1. Amount of precipitated $\mathrm{CaCO}_{3}$ at soil depths of $0,2.5$ and $5 \mathrm{~cm}$ after applying MICP with pouring and mixing method ( $\mathrm{n}=3$ ). (a) Medium sand, (b) Fine sand, (c) Loamy fine sand, (d) Loam
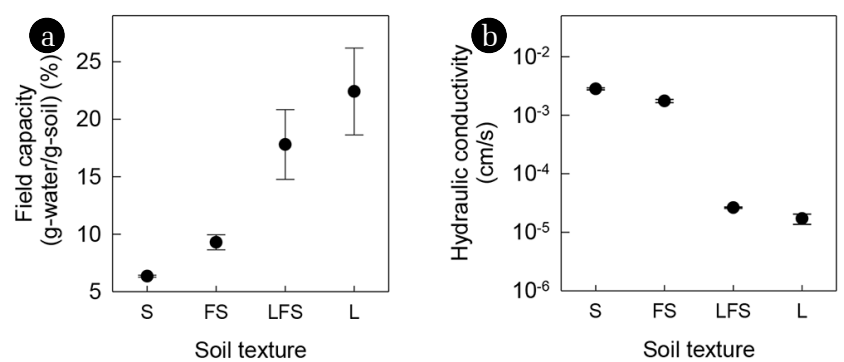

Fig. 2. Soil properties of soils used in this study $(n=3)$. (a) Field capacity, (b) Hydraulic conductivity

As shown in Fig. 2(b), hydraulic conductivity showed a bigger deviation among soils. Medium and fine sand exhibited a scale of $10^{-3} \mathrm{~cm} / \mathrm{s}$ (i.e., $2.81 \times 10^{-3}, 1.75 \times 10^{-3} \mathrm{~cm} / \mathrm{s}$, respectively) but loamy fine sand and loam exhibited a much lower scale of $10^{-5}$ $\mathrm{cm} / \mathrm{s}$ (i.e., $2.63 \times 10^{-5}, 1.70 \times 10^{-5} \mathrm{~cm} / \mathrm{s}$, respectively) indicating a restricted permeation of the solution. Calcite precipitation takes about four hours to be fully accomplished [6]. Therefore, in loamy fine sand and loam, although they have enough field capacity, due to their hydraulic conductivity, MCP-inducing solution cannot reach the soil depth of 2.5 and $5 \mathrm{~cm}$ in time for calcite precipitation. However, these results were only restricted to the inapplicability of pouring method on loamy fine sand and loam and insufficient to define the difference between medium sand and fine sand. Fine sand had a hydraulic conductivity of $1.75 \times 10^{-3} \mathrm{~cm} / \mathrm{s}$ which provides sufficient time to precipitate calcite until $5 \mathrm{~cm}$ depth. Also, since medium sand which had the smallest field capacity of $6.35 \%$ demonstrated even distribution of calcite, field capacity could not also explain what made the difference between medium sand and fine sand.

\subsection{Influence of Microbial Penetration on MICP Applicability}

Since hydraulic conductivity could only explain the absence of calcite in deeper soil for loamy fine sand and loam, penetrability of $S$. pasteurii was then tested by measuring urease activity at three depth points, 0, 2.5 and $5 \mathrm{~cm}$. From Fig. 3, urease activity of $S$. pasteurii was detected only on the surface in loamy fine sand and loam, where medium sand and fine sand showed even activity at all depths. Hence, $S$. pasteurii being unable to penetrate through the pores was an additional reason for uneven calcite distribution in loamy fine sand and loam after pouring method application.

The influence of calcium ion on microbial penetration was examined by measuring microbial urease activity at three depths using $S$. pasteurii and calcium ion solution. As a result, in medium sand, shown in Fig. 4(a), the presence of calcium ion slightly decreased the surface penetration rate of $S$. pasteurii from $74 \%$ to $52 \%$ but did not significantly alter the even distribution of $S$. pasteurii. Furthermore, as shown in Fig. 1(a), the decreased amount of $S$. pasteurii at $5 \mathrm{~cm}$ depth was enough to induce calcite precipitation more than $10 \mathrm{mg} / \mathrm{g}$-soil. However, in fine sand as shown in Fig. 4(b), addition of calcium ion greatly inhibited the penetration of S. pasteurii. $78 \%$ of $S$. pasteurii penetrated the soil surface without calcium ion but with calcium ion, only $20 \%$ did so and the rest accumulated on the surface. Again, as shown in Fig. 1(b), the decreased amount of $S$. pasteurii at $5 \mathrm{~cm}$ depth was not enough to induce calcite precipitation more than $5 \mathrm{mg} / \mathrm{g}$-soil.

The pore size and particle size of soil exhibits linear relationship $\left(d_{\text {pore }}=R_{x}{ }^{*} d_{\text {particle }}\right)$ [30]. As particle size of soil decreases from medium sand to loam, so does the pore size. Therefore, since the pore size of soils determines the penetration of $S$. pasteurii, it could be seen that loamy fine sand and loam have pores smaller than $S$. pasteurii, where medium sand and fine sand have bigger ones letting $S$. pasteurii penetrate through the pores. Likewise,
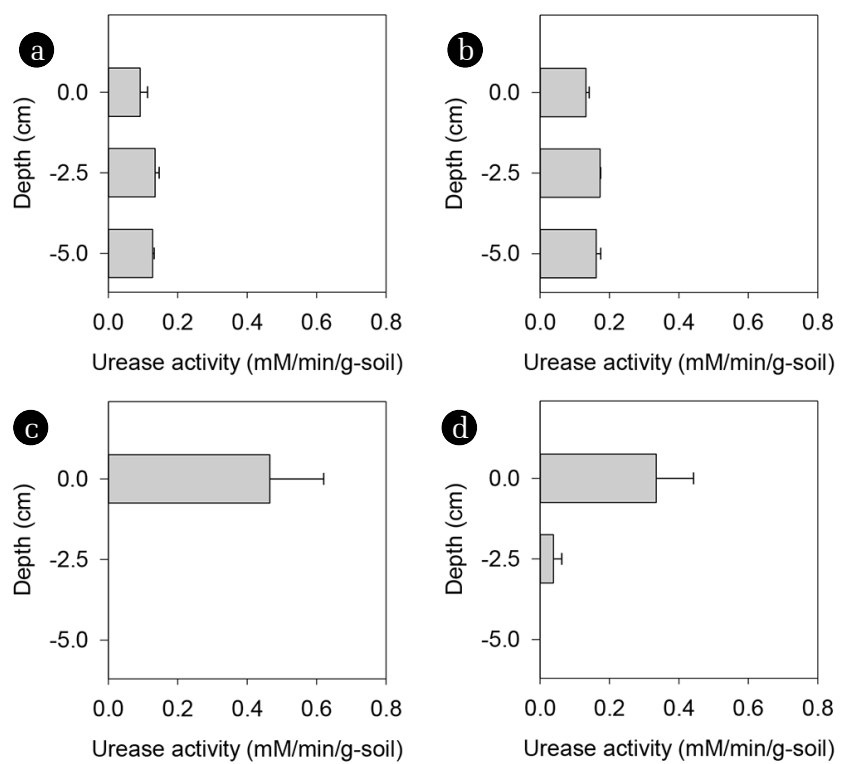

Fig. 3. Microbial urease activity at $0,2.5$ and $5 \mathrm{~cm}$ soil depths $(\mathrm{n}=3)$. (a) Medium sand, (b) fine sand, (c) Loamy fine sand, (d) Loam 

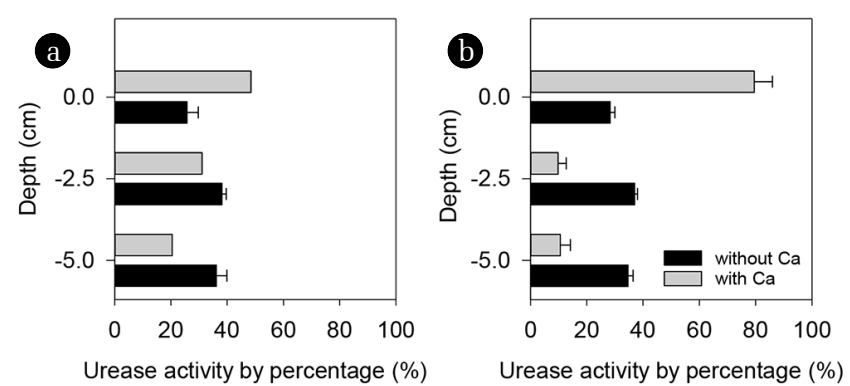

Fig. 4. Microbial urease activity at $0,2.5$ and $5 \mathrm{~cm}$ soil depths in the presence of calcium ion ( $\mathrm{n}=2$ for medium sand, $\mathrm{n}=3$ for fine sand). (a) Medium sand, (b) Fine sand.
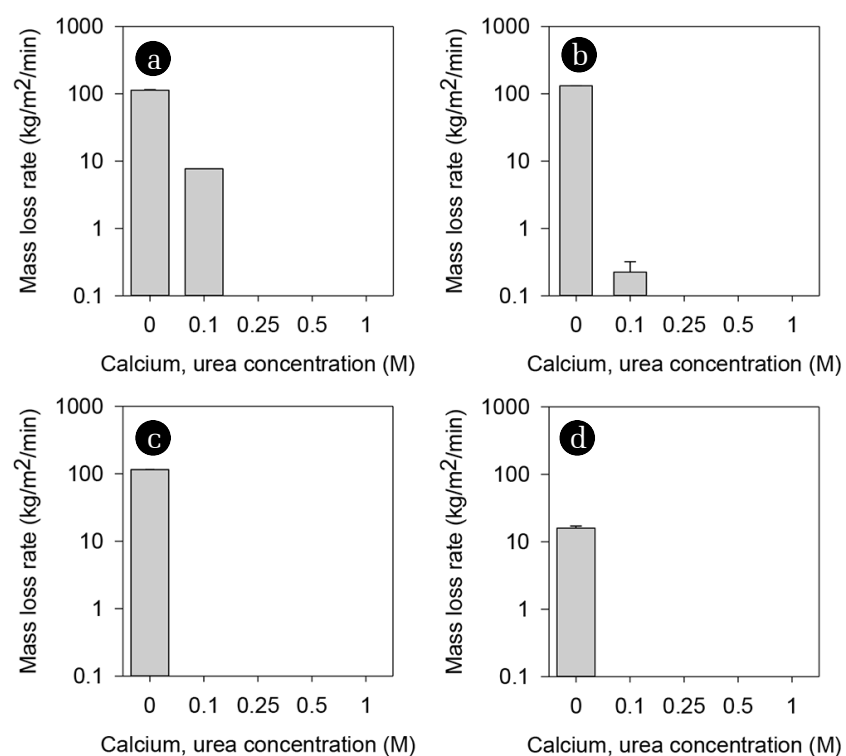

Fig. 5. Wind erosion rate at $15 \mathrm{~m} / \mathrm{s}$ wind velocity after applying MICP with $0,0.1,0.25,0.5$ and $1 \mathrm{M}$ each of calcium ion and urea ( $\mathrm{n}=3$ ). (a) Medium sand, (b) Fine sand, (c) Loamy fine sand, (d) Loam.

according to J. C. Santamarina et al. [31], soils with clay particles had pores that trapped bacteria whereas soils with particles larger than silt had traversable pore throats.

However, when calcium ion is introduced to the $S$. pasteurii solution, calcium ions can serve as aggregate inducer between $S$. pasteurii particles. $S$. pasteurii has a negative net surface charge which can draw cations from its surroundings [10]. Especially for calcium ions, they tend to accumulate on the cell surface rather than being absorbed for microbial metabolic processes [32]. During MICP application, the attached calcium ions on cell surface serves as nucleation sites of calcites. However, without urea hydrolysis to provide ample amount of carbonate ions, calcium ions attached to one cell can draw other cells rather than being precipitated as calcites. By playing a role as a bridge between cells, S. pasteurii aggregates are formed making its penetration through pore throats more difficult. During the experiment, white particulates were observed immediately when calcium solution and $S$. pasteurii solution were mixed together. Hence, the impermeability of $S$. pasteurii in medium sand may be due to the aggregation of $S$. pasteurii larger than the pore size of medium sand. From the results above, it could be concluded that the conventional pouring method was only applicable to medium sand and from fine sand to finer soils, mixing method was more efficient.

\subsection{Increased Wind Erosion Resistance After MICP Application}

Finally, MICP was applied by using appropriate methods for each soil types with different concentration of calcium and urea (i.e., $0.1,0.25,0.5$ and $1 \mathrm{M}$ ). After applying MICP, the surfaces of the samples were exposed to $15 \mathrm{~m} / \mathrm{s}$ wind at the angle of $10^{\circ}$. The initial and final mass were measured to calculate the mass loss rate of each samples. As shown in Fig. 5, medium sand and fine sand proved to be stable when applied with higher concentration of MICP-inducing solution than $0.25 \mathrm{M}$ and loamy fine sand and loam proved to be so from $0.1 \mathrm{M}$. The lower required concentration on loamy fine sand and loam may be due to the already existing cohesion of soil caused by clay particles. The threshold friction wind speed is smallest for soil particle size near $100 \mu \mathrm{m}$. As soil particles get finer than $100 \mu \mathrm{m}$, interparticle cohesive forces increases rapidly, thus, higher wind speed is needed for wind erosion. [24]. In other words, less amount of calcite is needed to resist the same wind power as the size of soil particles decreases. This may be the reason why lower concentration of calcium and urea is needed to acquire wind erosion resistance in loamy fine sand and loam.

\section{Conclusions}

MICP was successfully applied to four soil types (i.e., medium sand, fine sand, loamy fine sand and loam) with pouring and mixing methods, endowing wind erosion resistance to all soil samples. Thus, this study has broadened MICP application from sands to soils that are finer than fine sand that contain silt, clay particles by adapting mixing method. Hence, the broad application of MICP for further benefits such as, increasing soil strength and stiffness [7, 11-12] or bioimmobilizing heavy metals [14-15] can be projected on soils containing silt, clay particles. Furthermore, since soils can acquire sufficient wind erosion resistance, MICP will be beneficial for lands that are exposed to extreme wind erosion such as major deserts in China (Takla Makan Desert, Gobi Desert, Loess Area) that have versatile soil composition [22-23].

\section{Acknowledgment}

This work was supported by Korea Environment Industry \& Technology Institute(KEITI) through SEM(Subsurface Environment Management) project, funded by Korea Ministry of Environment (MOE)(2018002450002).

\section{Author Contributions}

S.H.C. (Masters Student) conducted all the experiments and wrote 
this article. H.Y.C. (Ph. D. student) supervised the experiments and helped writing this article. K.P.N. (professor) is the corresponding author, confirming the final version of this article.

\section{References}

1. Griffin DW. Atmospheric movement of microorganisms in clouds of desert dust and implications for human health. Clin. Microbiol. Rev. 2007;20:459-477.

2. Cao S. Why large-scale afforestation efforts in China have failed to solve the desertification problem. ed: ACS Publications, 2008.

3. Gong S, Zhang X, Zhao T, McKendry I, Jaffe D, Lu N. Characterization of soil dust aerosol in China and its transport and distribution during 2001 ACE-Asia: 2. Model simulation and validation. J. Geophys. Res-Atmos. 2003;108.D9

4. Sharratt B, Vaddella V, Feng G. Threshold friction velocity influenced by wetness of soils within the Columbia Plateau. Aeolian Res. 2013;9:175-182.

5. Lee H, Kim MY, Park SH. A Comparative Review of Wind-Blown Dust Emission Models. J. Korean Soc. Atmos. 2019;35:149-171.

6. Bang SS, Galinat JK, Ramakrishnan V. Calcite precipitation induced by polyurethane-immobilized Bacillus pasteurii. Enzyme Microb. Tech. 2001;28:404-409.

7. Whiffin VS. Microbial $\mathrm{CaCO}_{3}$ precipitation for the production of biocement [dissertation]. Perth: Murdoch Uni.; 2004.

8. DeJong JT, Fritzges MB, Nüsslein K. Microbially induced cementation to control sand response to undrained shear. J. Geotech. Geoenviron. 2006;132.11:1381-1392.

9. Grabiec AM, Klama J, Zawal D, Krupa D. Modification of recycled concrete aggregate by calcium carbonate biodeposition. Constr. Build Mater. 2012;34:145-150.

10. Stocks-Fischer S, Galinat JK, Bang SS. Microbiological precipitation of $\mathrm{CaCO}_{3}$. Soil Biol. Biochem. 1999;31:1563-1571.

11. Van Paassen L, Pieron M, Mulder A, Van der Linden T, Van Loosdrecht M, Ngan-Tillard D. Strength and deformation of biologically cemented sandstone. In: Proceedings of the ISRM Regional conference EUROCK; 2009. p. 405-410.

12. Xu Z, Bai T, Pang Y, Zhou F, Huang J. Experimental Study of the Filling Effect of MICP Microbial Grouting in Silt. In: International Conference on Architectural Engineering and Civil Engineering; 2016.

13. De Muynck W, De Belie N, Verstraete W. Microbial carbonate precipitation in construction materials: a review. Ecol. Eng. 2010;36:118-136.

14. Yang J, Pan X, Zhao C, et al. Bioimmobilization of heavy metals in acidic copper mine tailings soil. Geomicrobiol. J. 2016;33: 261-266.

15. Kang CH, Kwon YJ, So JS. Bioremediation of heavy metals by using bacterial mixtures. Ecol. Eng. 2016;89:64-69.

16. Lambert S, Randall D. Manufacturing bio-bricks using microbial induced calcium carbonate precipitation and human urine. Water Res. 2019;160:158-166.

17. Tian K, Wu Y, Zhang H, Li D, Nie K, Zhang S. Increasing wind erosion resistance of aeolian sandy soil by microbially induced calcium carbonate precipitation. Land Degrad. Dev. 2018;29:4271-4281

18. Maleki M, Ebrahimi S, Asadzadeh F, Tabrizi ME. Performance of microbial-induced carbonate precipitation on wind erosion control of sandy soil. Int. J. Environ. Sci. Technol. 2016;13: 937-944.

19. Bang SC, Min SH, Bang SS. KGS Awards Lectures: application of microbiologically induced soil stabilization technique for dust suppression. Geo-Engineering. 2011;3:27-37.

20. Gu J, Suleiman MT, Bastola H, Brown DG, Zouari N. Treatment of Sand Using Microbial-Induced Carbonate Precipitation (MICP) for Wind Erosion Application. In: International Foundations Congress \& Equipment Expo; 2018. p. 155-164.

21. Wang H, Jia X, Xiao J, Shi X. Provenance and geochemical characteristics of the silt and clay fraction in the Taklamakan Desert, Northwestern China. Arid Land Res. Manag. 2012;26: 85-102.

22. Addison J, Friedel M, Brown C, Davies J, Waldron S. A critical review of degradation assumptions applied to Mongolia's Gobi Desert. Rangeland J. 2012;34:125-137.

23. Tan WF, Zhang R, Cao H, et al. Soil inorganic carbon stock under different soil types and land uses on the Loess Plateau region of China. Catena. 2014;121:22-30.

24. Shao Y, Lu H. A simple expression for wind erosion threshold friction velocity. J. Geophys. Res-Atmos. 2000;105:22437-22443.

25. USEPA. SW-846 Test Method 9081: Cation-Exchange Capacity of soils (sodium acetate) [Internet]. USEPA; c1986 [cited 05 December 2019]. Available from: https://www.epa.gov/hw-sw846/ sw-846-test-method-9081-cation-exchange-capacity-soils-sodiumacetate.

26. Gillman G, Sumpter E. Modification to the compulsive exchange method for measuring exchange characteristics of soils. Soil Res. 1986;24:61-66.

27. Lauchnor EG, Topp D, Parker A, Gerlach R. Whole cell kinetics of ureolysis by S porosarcina pasteurii. J. Appl. Microbiol. 2015;118:1321-1332.

28. Zou X, Li J, Cheng H, et al. Spatial variation of topsoil features in soil wind erosion areas of northern China. Catena. 2018;167:429-439.

29. Qiang M, Chen F, Zhou A, Xiao S, Zhang J, Wang Z. Impacts of wind velocity on sand and dust deposition during dust storm as inferred from a series of observations in the northeastern Qinghai-Tibetan Plateau, China. Powder Technol. 2007;175: 82-89.

30. Wu L. Relationship between pore size, particle size, aggregate size and water characteristics [dissertation]. Corvallis: Oregon State Univ.; 1987.

31. Santamarina JC, Rebata-Landa V. Mechanical limits to microbial activity in deep sediments. Geochem. Geophy. Geosy. 2006;7:11.

32. Silver S, Toth K, Scribner H. Facilitated transport of calcium by cells and subcellular membranes of Bacillus subtilis and Escherichia coli. J. Bacteriol. 1975;122:880-885. 